\title{
Biotic Factors Affecting Ecosystem Services in Urban and Peri-Urban Forests in Italy: The Role of Introduced and Impending Pathogens and Pests
}

\author{
Salvatore Moricca * (D), Matteo Bracalini, Francesco Croci, Sara Corsinovi, Riziero Tiberi, \\ Alessandro Ragazzi and Tiziana Panzavolta ${ }^{(D)}$ \\ Department of Agrifood Production and Environmental Sciences, Plant Pathology and Entomology Division, \\ University of Florence, Piazzale delle Cascine, 28, 50144 Florence, Italy; matteo.bracalini@unifi.it (M.B.); \\ francesco.croci@unifi.it (F.C.); saracorsinovi@libero.it (S.C.); riziero.tiberi@unifi.it (R.T.); \\ alessandro.ragazzi@unifi.it (A.R.); tiziana.panzavolta@unifi.it (T.P.) \\ * Correspondence: salvatore.moricca@unifi.it; Tel.: +39-055-275-5864
}

Received: 29 November 2017; Accepted: 19 January 2018; Published: 26 January 2018

\begin{abstract}
The present-day phytosanitary disasters caused by biological invasions are afflicting urban and peri-urban forest stands worldwide, as well as the varied services they normally provide. In Europe, we are witnessing an alarming situation due to an increasing introduction of infectious diseases and pests. The authors present an up-to-date list of alien microbial pathogens and insect pests affecting urban greening that have been accidentally imported in Italy or that are likely to be introduced. Information about the biology, epidemiology, ethology, and control of these invasive organisms is provided. For each species, the current geographical distribution, including newly-colonized areas, is also given, as well as the chronological progression of its occurrence. Particular detail is used for describing symptoms - the key diagnostic elements for appropriate and timely phytosanitary management. This paper will benefit urban forest management, which is a crucial factor in maintaining the social and ecological viability of urban green spaces, as well as ecosystem services. The importance of engaging citizens in community-based monitoring of urban greenspaces for tracking the location, abundance, and pathways of invasive pathogens and pests will also be touched upon.
\end{abstract}

Keywords: microbial pathogens; insect pests; biotic invaders; forest ecological value; ecosystem services; citizen science

\section{Introduction}

Due to the global trend towards urbanization, in-city and peri-urban forests will play an increasingly important role in the future. The wellbeing of metropolitan populations, especially in megacities, will increasingly depend on ecosystem services provided by urban green spaces. Urban and peri-urban forests, in addition to ensuring valuable traditional goods such as timber, pulp, fiber, and food, also furnish a series of socio-economic benefits, including: carbon sequestration and storage; water purification; flood risk reduction; biodiversity conservation; the mitigation of atmospheric and acoustic pollution; air quality and urban microclimate improvements; and the enhancement of cities' aesthetics to further boost tourism, as well as providing recreational and cultural opportunities, such as environmental awareness. This entire array of services is directly affected by the parasitic action of diseases and pests, in particular the introduced ones, which alter the stability of these delicate ecosystems, disrupting food chains, modifying the structure and composition of biocenoses, and reducing the ecological, aesthetic, and amenity value of tree stands [1]. 
Not by chance, the introduction of alien species is considered worldwide one of the greatest dangers to biodiversity, as well as a possible cause of serious damage to human health and of heavy financial losses for entire industries [2-5]. Although humans, over the millennia, have transported and introduced plants and animals (and unintentionally microbes and pests harbored in these goods), usually for economic gain, these phenomena have assumed particular importance since 1500. In fact, following the discovery of the Americas and the birth of colonialism, the movement of goods and people to and from different countries has increased [6]. Nowadays, we are witnessing a substantial number of introductions of alien organisms as never before in mankind's history. In fact, the last century's societal transformations, specifically its increased circulation of humans (e.g., for trade, tourism, etc.), goods, and food, caused the problem to increase exponentially. The international trade in seeds, cuttings, seedlings, timber, and vegetables, for instance, offers these unwanted "hitchhikers", i.e., the plant pathogens and pests, more and more opportunities to move to new territories. Whereas in the past these agents were confined within their own distribution areas, their rate of migration being constrained by their own natural spreading ability and biogeographical barriers $[7,8]$, now, in a world without borders, their extra-range dispersal has been greatly facilitated. Furthermore, anthropic disturbance to natural systems reworks substrates and the physical environment more swiftly and vastly than before. The construction of roads, power lines, and buildings, in addition to changes in land management and deforestation, for example, alter the structure of ecosystems, communities, and populations, modifying interactions between species and inducing the release of resources. All these transformations promote biological invasions, by creating vacant spaces that represent open "windows of opportunity" for alien species [5].

The need to predict and control the potential effects of these introductions involves dealing with a further hurdle: climate change. Local, regional, and global changes in temperature, caused by the massive introduction of greenhouse gases (carbon dioxide, nitrous oxide, and methane) into the atmosphere, are potentially capable of modifying the global distribution of organisms [9-13]. In fact, ongoing climate change could significantly boost the development and survival of several potentially harmful pathogens and pests, whose presence nowadays is limited to certain areas by otherwise-unsuitable environmental conditions [14]. As a result, some exotic species, as well as some native ones, have started spreading pervasively into natural or urban ecosystems. We cannot overemphasize how, in urban settings, due to their high level of artificiality, modifications in climate are more sudden and more severe than in natural environments [15].

In this paper we will deal with the most harmful exotic plant pathogens and pests that have been accidentally introduced in Italy and that have caused significant damage to some of the major tree species in urban as well as in natural areas. In addition, we will discuss alien diseases and pests not yet introduced, but whose possible introduction might seriously compromise ecosystems' resilience and services (Table 1). Trees attacked by pathogens and insects often fall into a state of physiological and structural decline, thus affecting both their aesthetic value and their usability by citizens. Such decline may lead to tree dieback and mortality, which, of course, would heavily impact ecosystem services. In some cases, pathogens and pests attack trees without inducing visible symptoms, but they nevertheless undermine the stability of apparently healthy trees. These hazardous trees constitute a serious risk to citizens' safety; once recorded, they then require some form of management, reducing the green spaces' accessibility and usability [16]. 
Table 1. Main introduced and impending diseases and insect pests that are harmful for plants in urban and peri-urban areas in Italy.

\begin{tabular}{|c|c|c|c|c|c|c|}
\hline Plant Host & Fungi and Chromista & Bacteria & Insects/Nematodes & Native Range & $\begin{array}{l}\text { Year of First } \\
\text { Report in Italy }\end{array}$ & $\begin{array}{c}\text { Current Diffusion in } \\
\text { Italy }\end{array}$ \\
\hline \multicolumn{7}{|l|}{ Broadleaves } \\
\hline \multirow{2}{*}{ Ulmus spp. } & \multirow[t]{2}{*}{$\begin{array}{c}\text { Ophiostoma ulmi s.s., O. } \\
\text { novo-ulmi }\end{array}$} & & & Asia & $1900 \mathrm{~s}$ & pandemic \\
\hline & & & Aproceros leucopoda & Asia & 2009 & northeastern areas \\
\hline \multirow{2}{*}{ Platanus spp. } & \multirow[t]{2}{*}{ Ceratocystis platani } & & & North America & $1960 \mathrm{~s}$ & widely distributed \\
\hline & & & Corythucha ciliata & North America & 1964 & widely distributed \\
\hline \multirow{4}{*}{ Quercus spp. } & $\begin{array}{c}\text { Biscogniauxia } \\
\text { mediterranea }\end{array}$ & & & North Africa & 1987 & widely distributed \\
\hline & Phytophthora ramorum & & & $\begin{array}{l}\text { northern/central } \\
\text { Europe }\end{array}$ & 2002 & Tuscany \\
\hline & Ceratocystis fagacearum & & & North America & - & not present \\
\hline & $\begin{array}{l}\text { Cronartium quercuum } \\
\text { f.sp. fusiforme }\end{array}$ & & & North America & - & not present \\
\hline \multirow{4}{*}{ Castanea spp. } & Cryphonectria parasitica & & & Asia & 1940 & widely distributed \\
\hline & Ceratocystis fagacearum & & & North America & - & not present \\
\hline & Cronartium quercuum & & & North America & - & not present \\
\hline & f.sp. fusiforme & & Dryocosmus kuriphilus & China & 2002 & widely distributed \\
\hline Acer spp. & Phytophthora acerina & & & probably Asia & 2014 & Lombardy \\
\hline $\begin{array}{c}\text { Aesculus } \\
\text { hippocastanum L. }\end{array}$ & & & Cameraria orhidella & probably Balkans & 1992 & widely distributed \\
\hline \multirow{2}{*}{ Fraxinus spp. } & \multirow[t]{2}{*}{$\begin{array}{l}\text { Hymenoscyphus } \\
\text { fraxineus }\end{array}$} & & & Asia & 2009 & Eastern Italy, Tuscany \\
\hline & & & Agrilus planipennis & Asia & - & not present \\
\hline Arecaceae spp. & & & $\begin{array}{c}\text { Paysandisia archon } \\
\text { Rhynchophorus ferrugineus }\end{array}$ & $\begin{array}{l}\text { South America } \\
\text { probably India }\end{array}$ & $\begin{array}{l}2002 \\
2004\end{array}$ & $\begin{array}{l}\text { widely distributed } \\
\text { widely distributed }\end{array}$ \\
\hline Olea europea L. & & Xylella fastidiosa & & $\begin{array}{l}\text { North America, } \\
\text { Brazil }\end{array}$ & 2013 & Apulia \\
\hline
\end{tabular}


Table 1. Cont.

\begin{tabular}{|c|c|c|c|c|c|c|}
\hline Plant Host & Fungi and Chromista & Bacteria & Insects/Nematodes & Native Range & $\begin{array}{l}\text { Year of First } \\
\text { Report in Italy }\end{array}$ & $\begin{array}{l}\text { Current Diffusion in } \\
\text { Italy }\end{array}$ \\
\hline \multicolumn{7}{|l|}{ Conifers } \\
\hline Cupressus spp. & Seiridium cardinale & & & California & 1951 & widely distributed \\
\hline $\begin{array}{c}\text { Chamaecyparis spp. } \\
\text { and Taxus spp. }\end{array}$ & Phytophthora lateralis & & & North America & - & Not present \\
\hline \multirow{6}{*}{ Pinus spp. } & Heterobasidion irregulare & & & North America & 2004 & Latium \\
\hline & Fusarium circinatum & & & North America & 2005 & eradicated \\
\hline & & & & Atlantic areas of & & \\
\hline & & & Matsucoccus feytaudi & $\begin{array}{l}\text { Morocco, Portugal, } \\
\text { Spain, and France }\end{array}$ & $1970 \mathrm{~s}$ & Liguria, Tuscany \\
\hline & & & Leptoglossus occidentalis & North America & 1999 & widely distributed \\
\hline & & & Bursaphelenchus xylophilus & North America & - & Not present \\
\hline \multirow{10}{*}{$\begin{array}{c}\text { Various } \\
\text { ornamentals }\end{array}$} & & $\begin{array}{l}\text { Erwinia } \\
\text { amylovora }\end{array}$ & & North America & 1991 & widely distributed \\
\hline & & & Hyphantria cunea & North America & 1981 & $\begin{array}{c}\text { northern and central } \\
\text { areas }\end{array}$ \\
\hline & & & Metcalfa pruinosa & North America & 1979 & widely diffused \\
\hline & & & Anoplophora chinensis & Far East & 2000 & $\begin{array}{c}\text { Lombardy, Latium, } \\
\text { Tuscany }\end{array}$ \\
\hline & & & Anoplophora glabripennis & Far East & 2007 & $\begin{array}{c}\text { Lombardy, Veneto, } \\
\text { Marche }\end{array}$ \\
\hline & & & Xylosandrus crassiusculus & Asia & 2003 & $\begin{array}{c}\text { Tuscany, Liguria, } \\
\text { Veneto }\end{array}$ \\
\hline & & & Xylosandrus germanus & Asia & 1992 & northeastern areas \\
\hline & & & Aromia bungii & East Asia & 2012 & Campania, Lombardy \\
\hline & & & Popillia japonica & northeast Asia & 2014 & Lombardy \\
\hline & & & Malacosoma disstria & North America & - & Not present \\
\hline
\end{tabular}

- = No date is given as the organism is currently not present. 


\section{Main Introduced Microbial Pathogens and Insect Pests}

This group includes plant pathogens and phytophagous insects that have been reported in our country since the beginning of the 1900s. We give here information about the origin, biology, and behavior of those species which play an important role in both rural and urban greenscapes; this will enable phytosanitary managers to deeply analyze different situations, as well as their consequences, and also to timely plan strategies for conserving tree heritage and the aesthetical, recreational, and ecological value of urban and peri-urban forests. Fungi, chromista, bacteria, and insects are dealt with in chronological order based on their first recorded occurrence in our country on a given host-tree.

\subsection{Fungi and Chromista}

\subsubsection{Broadleaves}

Ulmus spp.

Ophiostoma ulmi (Buisman) Nannf. sensu stricto and O. novo-ulmi Brasier are agents of DED (Dutch Elm Disease), a vascular disease of Ulmus spp., a devastating pandemic which has caused the disappearance of thousands of elms from many rural and urban areas [17]. O. ulmi sensu stricto was responsible for the disease outbreaks in Europe and North America between 1910 and 1930. It has been particularly studied in the Netherlands starting from the devastating outbreak of the 1920s (hence the name "Dutch Elm Disease"). The latter pathogen caused a second epidemic in Europe, North America, and Asia in the period between 1940 to 1990 [18,19]. Particularly susceptible, among European elm species, are the field elm (Ulmus minor Mill), the English elm (U. procera Salisb.), and the wych elm $(U$. glabra Huds.).

The microorganism survives as a saprophyte in the tissues of dead plants, where it is able to produce spores and conidia that are then collected and spread by bark beetles of the genus Scolytus Geoffroy. The infectious structures of the fungus, carried by bark beetles, develop in cortical tissues, penetrating the wood vessels, where they produce various types of conidia (Cephalosporium, Sporothrix, yeast-like form). These spread up to the apical organs, moving from vessel to vessel through areolate piths. The plant reacts by producing phenols and various types of exudates (bubbles, gels, tyloses) which plug xylem vessels, thereby obstructing the passage of sap, with consequential DED symptoms: chlorosis, leaf withering, curling, and bending of apical twigs. Symptoms first appear in May-June on a few branches, but then, very rapidly (even in just a few weeks), affect the whole plant. Cutting infected branches or twigs obliquely will reveal brown discoloration in the last growth rings of sapwood, characteristic of vascular infections, due to the depositing of the plant's defense substances. The lethality of the microorganism has also been linked to its production of cerato-ulmin, a protein involved in different phases of the infection process [20].

\section{Platanus spp.}

Ceratocystis platani (J.M. Walter) Engelbr. \& T.C. Harr., the agent behind the "blue stain canker" of Plane, is native to Pennsylvania (1928) and is found along all of the United States' Atlantic coast. It was first recorded in Europe in the 1960s, before being reported in all the areas of Italy where plane trees were growing [21]. Subsequently, starting from 1974, it was reported in France, Spain, Armenia, Switzerland, and finally (2003) in Greece.

This microorganism is a vascular pathogen with a double whammy, since it causes damage not only to the vascular system of the plane tree (Platanus $x$ acerifolia Aiton (Willd.), P. orientalis L. and the more tolerant $P$. occidentalis L.), penetrating through wounds and root anastomoses, but also to the bark, which the mycelium reaches through vascular rays. The invasion of the vascular system causes leaf chlorosis and rapid wilting, with twig and branch die-off throughout the entire crown. Infested bark presents slight discoloration, as well as modest longitudinal lesions and a slight indentation. The pathogen may be transmitted by cutting tools, sawdust, insects, and other animals (such as 
rodents). Blue stain canker's destructiveness is related to four factors: pathogen virulence; host susceptibility (due to the high genetic uniformity of plane trees, most of which are clones); high levels of pathogen sporulation; and the pathogen's ability to produce three forms of conidia. It also produces a hydrophobic protein, called cerato-platanin, whose role in pathogenesis is still being studied [22].

The impact of this disease on plane trees in Italy was so devastating that, for the first time in this country, a Presidential Decree was issued enforcing the compulsory felling and destruction of infected plane trees (ministerial decree 'DM' 03.09.87), which was then modified by another legislative measure (ministerial decree 'DM' 17.04.98).

Quercus spp.

Biscogniauxia mediterranea (De Not.) Kuntze is a thermophilic species, indigenous in Morocco, which has adapted well to the Italian climate. First reported in Italy on Turkey oak (Quercus cerris L.) about 30 years ago [23], it is now present in many Italian regions, including Sicily and Sardinia; the Lombardy region represents its current northernmost limit in Italy. The pathogen, which seemed at first confined to hosts of the genus Quercus L., has recently also been found on maple (Acer spp.), beech (Fagus sylvatica L.), and ash (Fraxinus excelsior L.) [24].

B. mediterranea causes a canker called "charcoal" after its black stromata erupt through the bark of infected trees. It is a latent pathogen with an endophytic phase, which takes advantage of trees' water-stress to fully deploy its virulence, contributing to plant death. Tree mortality is further accelerated by the deep lesions on the bark of twigs, branches, and trunks, caused by the fungus' stromata pushing from the inside towards the outside. Dissemination occurs through ascospores carried by wind and insects.

This fungus is having a strong impact on populations of Mediterranean oaks, being able to modify the structure and composition of oak forest ecosystems. For example, Turkey oak was until 1990 the dominant tree species in a mixed Turkey oak/pubescent oak (Quercus pubescens Willd.) forest at Ulignano (Pisa), Italy (Latitude $43^{\circ} 24^{\prime} 09^{\prime \prime} \mathrm{N}-$ Longitude $10^{\circ} 51^{\prime} 4^{\prime \prime}$ E). Starting from the 2000s, the thermophilic $B$. mediterranea, favored by rising temperatures, began spreading pervasively into this mixed stand, decimating Turkey oak individuals, so that only pubescent oak currently survives in the stand [25].

Currently, the pathogen to which the greatest attention is being paid in oak stands is the oomycete Phytophthora ramorum Werres, De Cock et Man in 't Veld. It is a fungus-like agent, with a mycelial thallus with chitin-less cell walls, a distinguishing feature in species belonging to the Phytophthora genus (kingdom Chromista). These microorganisms, called "water moulds" because they thrive in water, can also be found in the soil, where they remain viable in their resistant forms: oospores and chlamydospores. These spores, in the presence of water, germinate and colonize plants' hairy roots, but they remain latent until a state of physiological stress occurs. At this point, the pathogen becomes infectious, expressing all its virulence, and colonizing the roots, the root collar, and the basal portion of the trunk. Infection occurs at temperatures around $16-22{ }^{\circ} \mathrm{C}$, which favor chlamydospore development, sporangia formation and opening, and zoospore germination.

P. ramorum devastated several oak (Quercus spp.) and tanoak (Notholithocarpus densiflorus (Hook. \& Arn.) Manos, Cannon \& S. H. Oh) forests in North America [26]. The origin of the pathogen is unclear, although much evidence indicates that it may have been repeatedly introduced from Asia into North America and Europe. Until a few years ago, this microorganism had been reported in Europe mainly on ornamental shrubs, and solely from nurseries; however, in the last few years, it has been spreading aggressively in plantations of Japanese larch (Larix kaempferi (Lamb.) Carr.) in the UK [27]. In Italy, the pathogen was reported for the first time in 2002 in a nursery on the non-native Rhododendron yakushimanum Nakai in Piedmont [28]. More recently (2013), it was found on the native viburnum (Viburnum tinus L.) in nurseries near Pistoia (Latitude $43^{\circ} 55^{\prime} 48^{\prime \prime}$ N-Longitude $10^{\circ} 53^{\prime} 24^{\prime \prime} \mathrm{E}$ ) [29]. The host range of this pathogen is extremely broad, from shrubs (camellia, laurel, strawberry trees, etc.) to trees (ash, beech, chestnut, horse chestnut, larch, magnolia, etc.). 
On oak and larch, P. ramorum induces the syndromes called, respectively, "sudden oak death" and "sudden larch death". This pathogen, different from many congeneric species, is an "aerial" Phytophthora, also infecting and sporulating on twigs and branches [30]. In trees, infections produce widespread foliar necrosis and lead to death of the trunk, which exudes a blood-red substance; in fact, the term "bleeding" is used to define this characteristic symptom. The symptoms on shrubs are the wilting of leaves and shoots (leaf and shoot blight), which turn brown. From an epidemiological and evolutionary perspective, it must be pointed out that the infectious hosts, conducive of the disease, are shrubs, whereas trees are non-transmissive hosts and thus represent "dead ends" [31].

\section{Castanea spp.}

Around 1940, the fungal pathogen Cryphonectria parasitica (Murrill) M.E. Barr (Figure 1), the agent responsible for chestnut blight, appeared for the first time in Italy [32]. This exotic ascomycete, native to East Asia [33], and responsible for the devastation of the American chestnut (Castanea dentata (Marsh.) Borkh.) starting from the beginning of the 20th century in eastern North America [34], in a few decades, spread epidemically in European chestnut (C. sativa Mill.) forests along the entire Italian peninsula. In this country, it harmed valuable chestnut stands and killed millions of trees, both in coppices (a type of forest which is clear-cut at 12- to 20-year intervals for timber production, and regenerates by clusters of small stems resprouting from the stumps) and in orchards (regularly spaced, grafted trees grown for nut production). The attack of $C$. parasitica drastically altered the typical Italian hilly landscape, replacing the chestnut with other tree species (e.g., Turkey oak), and ruined a flourishing chestnut cultivation, then representing both an important source of food and a vital economic support for rural populations of many disadvantaged areas. Fortunately, in Italy, the natural transmission of fungal viruses in the Hypoviridae family led to the spread of hypovirulence in chestnut stands affected by chestnut blight. This natural biological control was possible due to a limited occurrence of different vegetative compatibility (VC) types in the pathogen's populations, combined with favorable environmental conditions and other not well-identified epidemiological factors [34].

\section{Fraxinus spp.}

At the beginning of the '90s, a lethal disease in European ash (F. excelsior L.) and narrow-leaved ash (F. angustifolia Vahl.) emerged in north-eastern Poland. Symptoms included the necrosis of leaves, twigs, and stems, accompanied by the wilting and dieback of shoots and dark reddish-brown discoloration of the bark [35]. The causal agent of the disease was identified by Kowalski in 2001 [36] and later ascribed to the new mitosporic ascomycete Chalara fraxinea T. Kowalski sp. nov. [37]. This fungus has its sexual stage in the discomycete Hymenoscyphus fraxineus Baral, Queloz \& Hosoya (syn. Hymenoscyphus pseudoalbidus Queloz, Grünig, Berndt, T. Kowalski, T.N. Sieber \& Holdenr.) [38].

This fungus, probably introduced from Asia [39], currently poses a serious menace to F. excelsior L. growth and survival in large parts of its native distribution area. The agents of ash dieback, observed in 2010 along the Italian-Slovenian border [40], spread westwards in the following years, colonizing the southern slope of the Alps in the Trentino region [41]. H. fraxineus has recently been reported in the Apennines (central Italy), the most southern border of its current range in Europe [42]. There is great concern for a possible epidemic spread of this microorganism in the Italian peninsula, both because it seems to be endowed with a remarkable adaptability to the Mediterranean climate, and because, in addition to F. excelsior (the most susceptible species) and F. angustifolia Vahl, other species of ash, among which F. angustifolia subsp. angustifolia, F. oxyphylla M.Bieb. and some other ornamental cultivars (which are all sensitive to the disease), are being increasingly employed in urban and peri-urban areas (especially in tree-lines) and in the nursery industry. The susceptibility of the South European flowering ash (F. ornus L.), a very common species in southern European countries and throughout Italy, is currently unknown. 


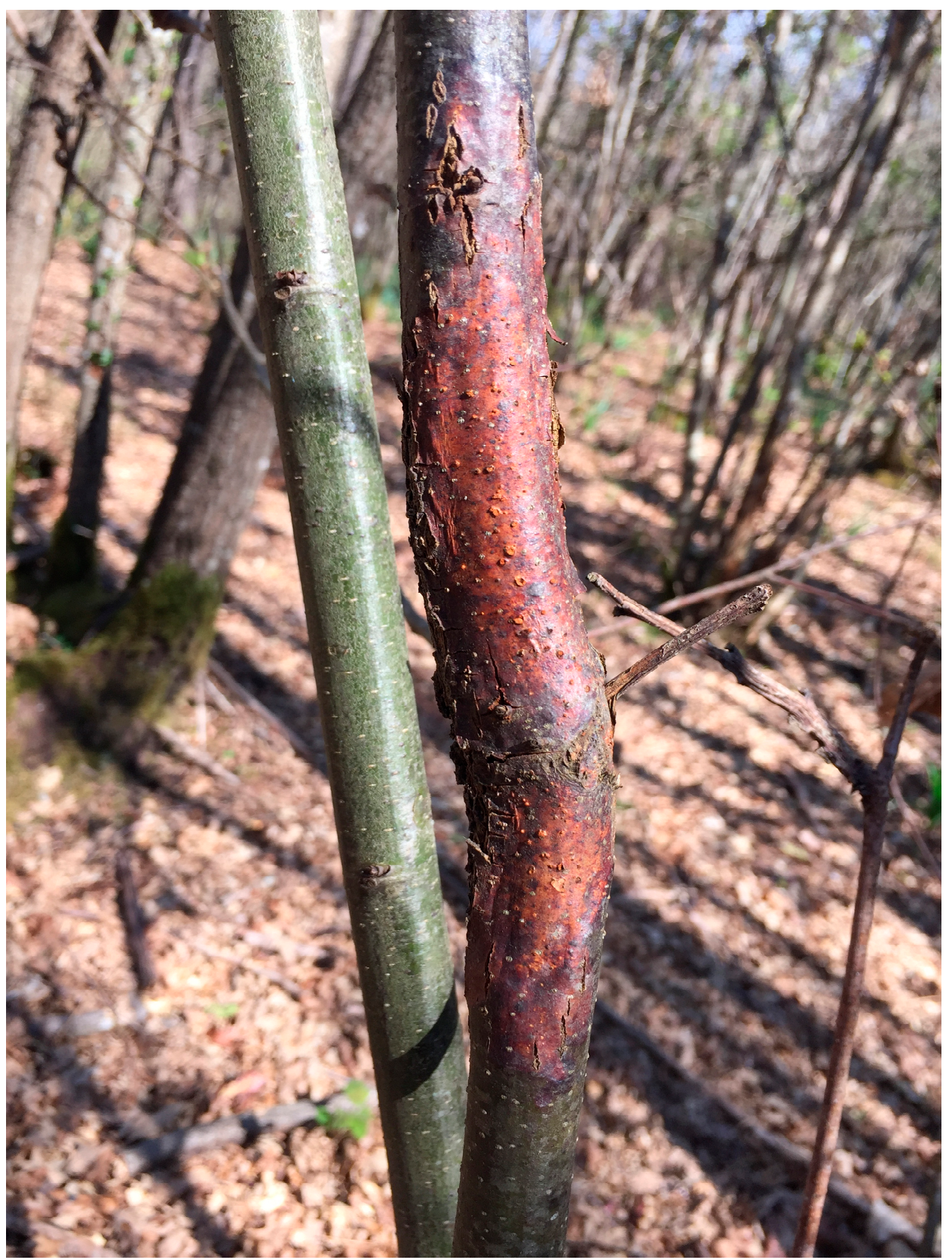

Figure 1. A canker on the stem of a young European chestnut (Castanea sativa) tree. The characteristic orange-brown discoloration of the bark, with bark cracks and yellowish-to-orange stromata containing locular pycnidia (conidiomata) are clearly visible. Under favorable moist conditions, yellow tendrils consisting of sticky conidia extrude from pycnidia.

Acer spp.

A new, harmful pathogen has been reported in northern Italy in recent years: Phytophthora acerina B. Ginetti, T. Jung, D.E.L. Cooke, S. Moricca sp. nov., the agent behind Acer pseudoplatanus L.'s extensive die-off. The origin of this oomycete is uncertain but, like the other members of the P. citricola complex (Clade 2), it could have originated in Asia. On A. pseudoplatanus L. it produces a specific set of symptoms: crown transparency; cankers with exudates at the base of the trunk; dark orange cortical lesions; and brown-green pigmentation of the cambium and woody tissue. The damages this oomycete causes, its wide dissemination, and its high virulence have all recently attracted the attention of researchers [43]. 


\subsubsection{Conifers}

\section{Cupressus spp.}

The first report in Italy (Florence) of Seiridium cardinale (W.W. Wagener) B. Sutton \& I.A.S. Gibson, the agent responsible for "Cypress canker" or "Cypress blight" on Cupressus spp., dates to 1951 [44]. Epidemics followed over time with such an intensity that they compromised the survival of both the common cypress (Cupressus sempervirens L.) (Figure 2) and the Monterey cypress (C. macrocarpa Hartw. ex Gordon.). S. cardinale is native to California (1928), from whence it spread across all areas of cypress cultivation, making its appearance in Europe (France) in 1944. After the alarm was raised by Graniti [45], who feared a pandemic, the disease began to regress due to a number of factors: climate warming, which reduced the pathogen's fitness (the higher summer temperatures of the last few decades inhibited the pathogen's survival and reproduction); use of resistant propagation material (based on the pathogen's limited genetic variation, which reproduces only asexually, clones with a sufficiently durable resistance were obtained); and a drastic reduction of the host population following the death of millions of trees (the most susceptible genotypes).

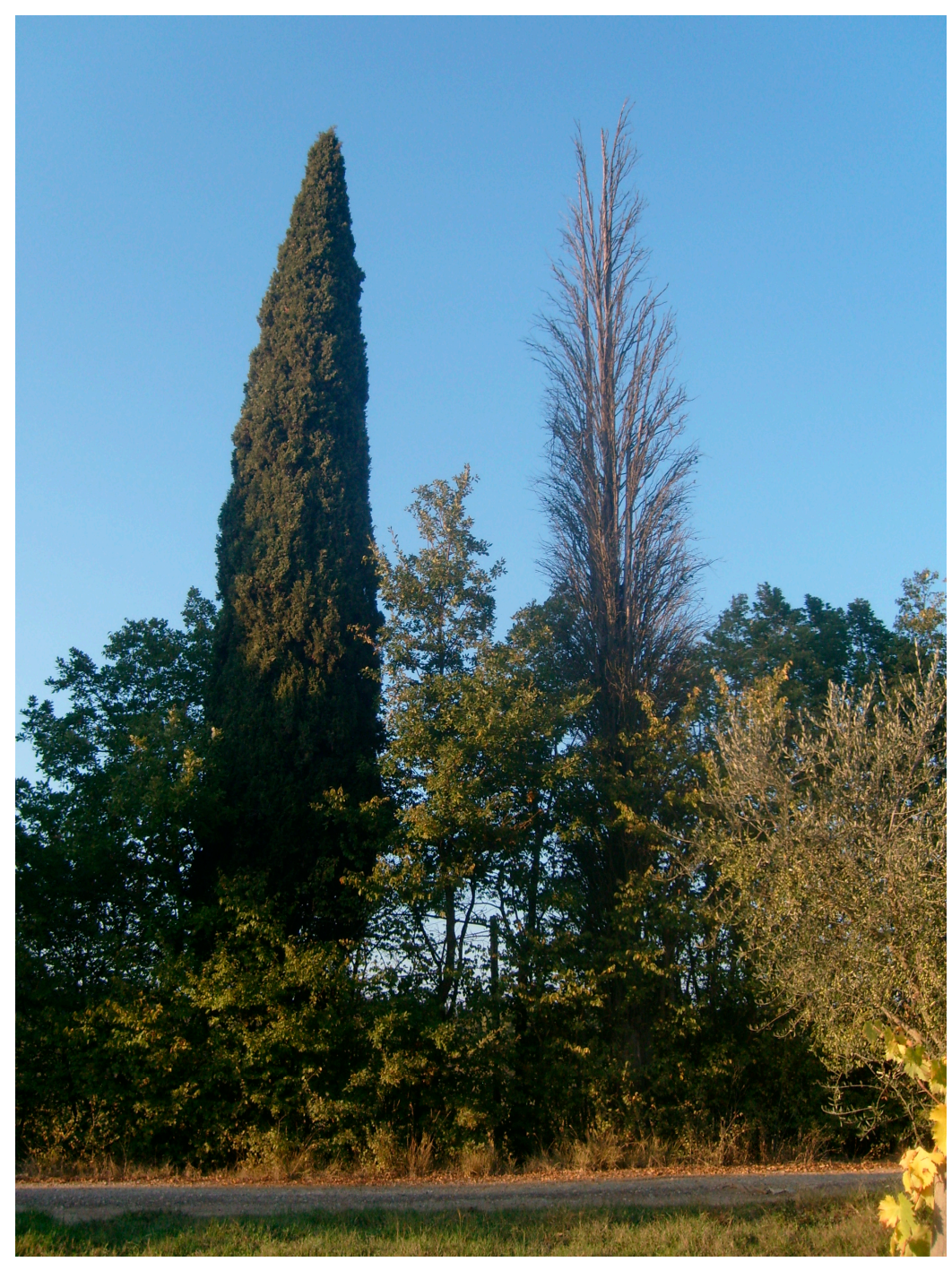

Figure 2. A common cypress (Cupressus sempervirens L.) tree killed by cypress blight next to a healthy-looking common cypress. Trees were located in a row along a road in a suburban area and had high ornamental and landscape value. The aesthetic damage is evident. 
The pathogen survives as a saprophyte in tissues of dead plants and it is especially spread by Phloeosinus aubei Perris and Orsillus spp. However, rain, resin, other animals (e.g., birds), and wind may also disperse fungal propagules. S. cardinale infects all woody organs of the plant, on which, in spring and in autumn, it produces acervuli (conidiomata) containing conidia. Fruiting bodies appear repeatedly during the growing season, considerably increasing the inoculum mass. Infected twigs, branches, and trunks show elongated cankers from which abundant resin flows. The area around the cankers tends to necrotize and the crown portion above the canker dies as soon as it girdles the stem. The first symptom, the one which should raise the alarm, however, is the necrosis of the apical twigs. Optimal conditions for infection are periods with high levels of humidity and high temperatures.

Pinus spp.

Several pine pathogens have been introduced into Italy. Some are leaf parasites of secondary importance in urban environments. Others, like Heterobasidion irregulare (Underw.) Otrosina et Garbelotto (ex intersterile Group P (or North American) of Heterobasidion annosum (Fr.) Bref. sensu lato), the agent behind "root rot and decay in conifers", have prompted a great deal of concern. This basidiomycete was reported in 2004 on stone pines (Pinus pinea L.) in Castel Porziano-Rome (Latitude $41^{\circ} 44^{\prime} 00^{\prime \prime} \mathrm{N}$-Longitude $12^{\circ} 24^{\prime} 00^{\prime \prime}$ E) [46]. It is suspected that it was accidentally introduced by the US Army during the Second World War with weapons crates made of infected pine wood. The pathogen belongs to the Heterobasidion annosum sensu lato species complex, along with other taxa. This complex is considered extremely dangerous in forestry, for its wide diffusion, the damages it causes, and its large number of hosts (200 taxa including many conifers) [47].

This microorganism normally enters pine stands through freshly-cut stump surfaces, on which basidiospores germinate and initiate the infection process. The fungus quickly colonizes the root system and moves to neighboring trees, and from tree to tree, through root anastomoses. The fruiting bodies (basidiomata), which constitute the fertile hymenium, form at the base of the tree; basidiomata are easily recognizable, being brick-red on the upper surface and white on the bottom. H. irregulare survives for a few years in the pine base. The enzymes it produces degrade the lignin, followed by wood decay, with the consequential loss of tree stability. The main symptoms are: yellowing of the needles, growth reduction, decay, and sometimes a release of resin at the base of the trunk and roots. In parks and other urban green areas, root rot and decay undermine the stability of trees, with high risks of falling.

In 2005, a distinctive symptomology, consisting of crown decline, dieback of twigs, and branches with bleeding cankers on the stem, accompanied by abundant resin flow, was observed on some Pinus halepensis Mill. and P. pinea L. individuals growing in urban parks and gardens in Apulia, in southern Italy. These symptoms strongly resembled those caused by the fearsome pitch canker agent: Fusarium circinatum Nirenberg \& O'Donnell (teleomorph Gibberella circinata). Isolation in purity unfortunately confirmed the presence of this pathogen [48]. First reported in North America, the pathogen currently also occurs in Central and South America, South Africa, Asia, and Europe. It is predominantly a wound parasite, which enters the tree through mechanical injuries or through holes produced by wood boring insects. Its dangerousness is also in its remarkable dispersal ability: through windborne conidia or by means of insect vectors [49]. F. circinatum is at present considered one of the most harmful pathogens affecting pines worldwide, infecting pines in planted forests, in urban parks, streets, and in nurseries [50]. The disease thus poses a global threat to pine, especially to artificial plantations of particularly susceptible hosts, such as Pinus radiata D. Don, a species that has been widely exploited in afforestation programs in Mediterranean countries, including Italy. Quashing the outbreak in Apulia seems to have been effective: this anamorphic ascomycete has, in fact, been declared (by the EPPO) eradicated from Italy. 


\subsection{Bacteria}

\subsubsection{Olea europea L.}

Olive trees (Olea europea) are widely exploited as ornamentals in the urban context in Mediterranean countries, particularly in central Italy. This tree species is currently under severe menace by the recently introduced bacterium Xylella fastidiosa Wells et al., which has been associated in Apulia (Salento peninsula, southern Italy, Latitude $41^{\circ} 15^{\prime} 00^{\prime \prime} \mathrm{N}$, Longitude $16^{\circ} 15^{\prime} 00^{\prime \prime} \mathrm{E}$ ) with the "quick decline syndrome" of olives [51].

This "fastidious" bacterium, native to the Americas (North America and Brazil), was reported in the nineties from Taiwan, and more recently (2013) in southern Italy. This xylem-limited species infects a wide range of hosts (more than 350 different plant species) in urban and rural environments [47].

The symptoms of this bacterial disease become visible on the leaves during the summer, with marginal necroses. Malformations induced by the disease first affect older leaves and, only later, the young ones. Infections by this bacterium cause early defoliation of the crown, so that attacked plants, with their leafless branches, are visibly suffering. The infection and its consequences impact the root system's functionality, to the detriment of both the vegetative state and plant physiology, leading to irregular succession of the phenological phases. X. fastidiosa is spread by various insects, such as leafhoppers and froghoppers [52]; thus, researchers should take into due account these vectors when defining control strategies. In the mild temperatures of southern Italy, this bacterium has found a favorable environment not only for surviving, but also for becoming highly virulent.

\subsubsection{Rosaceae}

About 120 plant species, all belonging to the Rosaceae family, are susceptible to fire blight, a harmful disease induced by Erwinia amylovora (Burrill) Winslow et al., a gram-negative bacterium in the Enterobacteriaceae family. This disease is devastating for members of the Pomoideae sub-family, which includes fruit trees (e.g., apple tree, pear tree, Japanese medlar, quince tree) and many ornamentals frequently employed in urban green areas such as hawthorn, cotoneaster, pyracantha, raspberry, and Photinia Lindl. Native to North America, it was reported in Europe for the first time in 1958 [53]. In subsequent years, the disease spread pervasively in several European countries: in France in 1978, in Greece around 1986/1989, in Switzerland in 1989, in Germany and Yugoslavia in 1990, and, finally, in Apulia, southern Italy in the early '90s [54,55]. E. amylovora causes the withering and necrosis of shoots, flowers, leaves, and fruits, as well as cankers on the branches. The bacterium disperses out from infected organs, during the growing season, by means of rain, insects, birds, and wind, onto the same plant or on nearby ones, where it penetrates through natural openings (e.g., flowers, stomata, lenticels, and hydatodes) or through wounds. The pathogen overwinters at the edges of branch cankers formed during the previous season; then, in spring, it begins to multiply, producing droplets of sweet exudate in times of high environmental humidity [56]. This bacterial disease is present at scattered foci in several Italian areas, the latest being reported in Latium (central Italy) in 2013 [57]. There are major concerns for its possible epidemic outbreak in apple orchards of the Trentino region. Eradication is made difficult by the widespread diffusion of the disease on ornamental host species, which often grow in urban areas interspersed with other vegetation.

\subsection{Phytophagous Insect Pests}

\subsubsection{Broadleaves}

\section{Ulmus spp.}

Aproceros leucopoda Takeuchi (Hymenoptera: Argidae) is a defoliating hymenopteran, native to Asia and associated with elm trees, which was first recorded in Italy in 2009 [58], where it was probably introduced with elms employed in horticulture or forestry. This insect is apparently still confined to 
northeastern areas, i.e., Friuli-Venezia-Giulia (site of introduction), and the province of Trento, where it was recorded in 2013 [59]. Here, infested elms showed defoliation rates above $70 \%$ along a $10-\mathrm{km}-\mathrm{long}$ riparian area. In Italy, $A$. leucopoda feeds in spring/summer, completing four generations per year. Attacked plants, if not completely defoliated, generally produce new leaves during the same year [60].

\section{Platanus spp.}

The sycamore lace bug, Corythucha ciliata (Say) (Hemiptera: Tingidae), native to North America, has been known in Italy since 1964, when it was recorded near Padua on plane trees (Platanus $\times$ acerifolia (Aiton) Willd.) growing inside an American military base [61]. It is a sap-sucking insect mainly associated with plane trees; from spring to autumn, it colonizes the underside of leaves for feeding and reproduction. Over the course of three consecutive generations, completed in one year, this species can cause severe discoloration of the foliar surface, with frequent cases of phylloptosis during the summer.

After first being recorded, the sycamore lace bug spread, within a decade, throughout the Italian peninsula and the islands. It currently still remains the most damaging insect for Platanus spp., well-known for its recurring aesthetic damage to the crown of attacked trees. In fact, planes are widely used in urban and suburban parks and gardens, for the imposing structure of the adult trees and for their large and dense crown.

\section{Aesculus hippocastanum L.}

A defoliator from the Balkan regions, specifically from Hungary, was recorded for the first time in Italy (South Tyrol) at the end of the last century: Cameraria orhidella (Deschka et Dimic) (Lepidoptera: Gracillariidae) [62]. It is a micromoth associated with horse chestnuts (Aesculus hippocastanum L.), a tree species frequently used in parks, gardens, and boulevards, on which the larvae of C. orhidella mine irregular galleries in the mesophyll. The insect completes up to four generations every year and can start a fifth, without completing it. Surveys carried out in Tuscany have highlighted that this leaf miner prefers horse chestnut trees with white flowers rather than the hybrids with pink flowers or the other species with red flowers [63].

C. orhidella damages the attacked trees not only directly, but also indirectly. Its larvae gradually destroy the mesophyll, resulting in direct aesthetic damage, as well as in physiological stress for the trees. In addition, the feeding activity of the larvae may promote the establishment of a leaf fungus, Guignardia aesculi (Peck) V. B. Stewart, which is associated with horse chestnuts.

\section{Castanea spp.}

Dryocosmus kuriphilus Yasumatsu (Hymenoptera: Cynipidae) is a gall wasp native to China and first reported in Italy and Europe in $2002[64,65]$ by means of infested imported plant material. The gall wasp induces the formation of galls in the new shoots of chestnut trees, preventing or reducing the differentiation of reproductive organs, thus compromising the chestnut production industry. The ministerial decree 'DM' of 30 October 2007, issued by the Italian Ministry of Agriculture (MiPAAF), to be applied for the mandatory fight against this pest, was abrogated with the DM of 25 August 2011. This serious pest, after a multi-year program of classic biological control with the exotic parasitoid Torymus sinensis Kamijo, currently seems to be under control in various areas of Italy.

\section{Arecaceae spp.}

Accidentally introduced in the last decade of the twentieth century in Europe, the Paysandisia archon (Burmeister) moth (Lepidoptera: Castniidae), native to South America, made its first appearance in Italy in 2002 and gradually came to settle in the central-southern regions of the peninsula, where it completes one generation per year [66]. The moth larvae feed on host plants belonging to the Arecaceae family. Palms attacked by this pest manifest specific signs and symptoms, which collectively contribute to a general decline of the leaves. The most characteristic aspects of $P$. archon infestations are the 
copious frass protruding from holes dug by the larvae in leaves and the stem and the presence of pupal exuviae outside. The extent of damage varies greatly depending on the palm species attacked; however, in many circumstances, the vegetative state of the plant is seriously compromised, especially when the number of active larvae inside the stem is high.

In the summer of 2004, in a plant nursery in the Pistoia area (Latitude $43^{\circ} 55^{\prime} 48^{\prime \prime}$ N-Longitude $10^{\circ} 53^{\prime} 24^{\prime \prime}$ E), Rhynchophorus ferrugineus (Olivier) (Coleoptera: Curculionidae) was recorded. Commonly known as the "red palm weevil", it is probably native to India, but it is now widespread all over Asia, where it causes severe damage to coconut plantations [67]. From Tuscany, the weevil has spread rapidly throughout Italy, including Sicily and Sardinia. Besides palm trees, the insect attacks other Arecaceae species, including those usually planted in parks, gardens, and boulevards, though with less severe damage. The ministerial decree ' $\mathrm{DM}^{\prime}$ ' of 9 November 2007, issued by the Italian Ministry of Agriculture (MiPAAF), and subsequently integrated and amended by the DM of 7 February 2011, provides guidance and rules to be applied for the mandatory fight against this pest. Adults are recognizable for their reddish-brown or rust-red color, which give it its common name. In Italy, $R$. ferrugineus appears to complete three partially-overlapping generations per year [68].

The attack of the weevil may not be visible on the plant for a long time, growing in the inner tissues of the palm trees; it becomes evident only when the infestation is at an advanced stage, at which point it is very difficult to control. Early symptoms are anomalies in the crown, which becomes droopy. During the final phase of the attack, the plant collapses, and consequently, R. ferrugineus adults abandon the attacked tree and move to a new palm tree. In Italy, palms are largely used for ornamental purposes and some monumental species may have a high aesthetic value.

\section{Various Ornamentals}

In the 1970s, Hyphantria cunea (Drury) (Lepidoptera: Erebidae), already known to occur in other European countries, was reported in Italy for the first time, specifically in Emilia Romagna [69]. This is a defoliating moth native to North America, associated with many broadleaves, as well as with numerous herbaceous and shrub species. Its favorite hosts are Acer negundo L. and Morus alba L., on which serious and repeated defoliation have resulted in significant damage to the crown, impacting their ornamental value. In Italy, H. cunea completes two generations per year, with the larvae of the second one being mainly responsible for the devastating defoliations.

Again, in the 1970s, another North American pest was recorded in Italy for the first time: Metcalfa pruinosa (Say) (Hemiptera: Flatidae) [70]. The species, commonly known as the "citrus flatid planthopper", prefers deciduous plants (dogwood, elm, oak, maple, willow, etc.), especially those taxonomically close to the ones occurring in its original distribution range. The rapid spread of this sap-sucker seems to be favored by vehicles (infestations have been observed along the roads), as well as by the high temperatures and high relative humidity present in colonized environments. M. pruinosa completes one generation per year, feeding on phloem and xylem sap, as well as on cellular contents taken from the epigeal organs of the infested trees. In summer, large amounts of honeydew produced and discarded by this sap-sucker can frequently be observed on the host plant's leaves. After initially high infestations, the population density of this pest decreased and at present it does not appear to be very damaging in Italy, although it may cause problems in nurseries.

At the beginning of the 21st century, Anoplophora chinensis (Forster) (Coleoptera: Cerambycidae), commonly known as the "Citrus longhorned beetle", and its congeneric species, Anoplophora glabripennis (Motschulsky) (Coleoptera: Cerambycidae), the "Asian longhorned beetle", were first recorded in Lombardy [71,72]. They are xylophagous longhorn beetles native to the Far East, which are associated with a large number of host plants. Usually, they develop one generation per year; however, depending on the environmental conditions, development may take up to two years. These beetles cause damage both to the lignified parts of the host, as well as to the not-yet-lignified green parts in the outer portion of the crown. In the former case, it is the larvae that dig long and winding galleries in the wood of the trunk, especially at the base, reducing the plant's stability. In the latter, it is 
the adults, which, after emerging, feed on young twigs, thus damaging both the green bark and the leaves. Adults emerge from attacked plants by excavating circular holes on the bark, easily detectable on both the trunk and the superficial roots. The introduction of $A$. chinensis Planch. into Italy is believed to be linked mainly to the bonsai trade; this may also be true for other European countries. The distribution of both species in Italy appears to be at present limited to certain areas; however, the possibility that they may spread quickly throughout the entire country is quite frightening. In fact, as early as 2008, A. chinensis was observed on ornamental trees in Rome [73], and in 2014 in Tuscany [74], where it was surely introduced unintentionally via the commerce of infested plant material. Moreover, A. glabripennis was recorded in Veneto in 2009 [75,76], and in three municipalities of the Marche region in 2013 [77]. Both species can cause serious damage to healthy fruit and ornamental trees; in fact, besides the damage to fruiting shoots, attacked plants are often killed, resulting in heavy economic losses. Two ministerial decrees, 'DM' of 15 February 2000 and 'DM' of 12 October 2012, issued by the Italian Ministry of Agriculture (MiPAAF), provide guidance and rules to be applied for the mandatory fight against these pests.

The first Italian record of Xylosandrus crassiusculus (Motschulsky) (Coleoptera: Curculionidae) dates to 2003, when it was observed inside insect traps in Tuscany [78]. Damages were then observed starting from 2007 in several areas of Liguria [79-81]. In Italy, though polyphagous on many tree species, this bark beetle has only been observed on Ceratonia siliqua L. individuals, in several gardens. Its larvae dig tunnels in the branches and shoots of infested trees, which are easily recognizable due to the frass cylinders protruding from their galleries. A congeneric species, Xylosandrus germanus (Blandford) (Coleoptera: Curculionidae), also polyphagous on conifers and broadleaves, has been occurring in Italy since the 1990s [82]. This Asian species is now dominant in European forests [83], while in the United States, it is considered one of the most harmful exotic pests, especially in plant nurseries [84].

Another xylophagous longhorn beetle, Aromia bungii (Faldermann) (Coleoptera: Curculionidae), which is also native to East Asia, was reported in Italy in 2012. It is a polyphagous species associated with ornamental broadleaves and many fruit trees [85]. The first reports of this beetle were in Campania (Latitude $41^{\circ} 00^{\prime} 00^{\prime \prime} \mathrm{N}$ - Longitude $14^{\circ} 30^{\prime} 00^{\prime \prime} \mathrm{E}$ ) [86], but it is feared to have spread more widely in central and southern Italy. In addition, in 2013, it was also reported on a peach tree in Lombardy [87]. The adults appear in spring; the typical signs of their presence are their circular emergence holes on the branches, trunk, and superficial roots of the attacked plants. These, like Anoplophora, feed on green bark, and the females lay their eggs on lignified organs. Newly hatched larvae then dig deep galleries in the wood; the abundant frass at the base of the trunk reveals their activity. This species develops one generation every two years. Wood packaging, wood, and wooden products of Prunus are probably its main transference pathways. A. bungii is a serious pest which can negatively impact the fruit production sector, as well as the production of wild cherry wood. It may kill susceptible trees within three or four years, and it is able to attack not only stressed trees, but also young and healthy ones [88].

Yet another recently-introduced beetle to Italy is the scarab beetle Popillia japonica Newman (Coleoptera: Scarabaeidae), native to northeast Asia and observed for the first time in Italy in 2014, in the Ticino area between Lombardy and Piedmont $[89,90]$. This species, associated with broadleaves, feeds on about 295 different host species. Its damage involves the erosion of leaves, which are literally skeletonized. In addition, their larvae harm the roots of herbaceous species; in fact, the most serious damage occurs to lawns, with the die-off of large areas. Normally, the beetle develops one generation per year; however, it takes two years to complete the cycle in colder environments [91]. Introduction of this species occurred by adult specimens on packaging or larvae hidden in soil around the roots of plants imported for planting. P. japonica (Thunb.) D. Don ex G. Don may attack various fruit trees, reducing the market value of the fruit. In addition, maize crops may be impacted, leading to malformed kernels and reduced yields. The ministerial decree 'DM' of 17 March 2016, issued by the 
Italian Ministry of Agriculture (MiPAAF), and subsequently integrated and amended by the 'DM' of 6 July 2017, provides guidance and rules to be applied for the mandatory fight against this pest.

\subsubsection{Conifers}

\section{Pinus spp.}

In 1972, Matsucoccus feytaudi (Ducasse) (Hemiptera: Margarodidae), the maritime pine (Pinus pinaster Aiton) bast scale, was first recorded in the Ventimiglia area (Latitude $43^{\circ} 47^{\prime} 00^{\prime \prime}$ N, Longitude $7^{\circ} 36^{\prime} 00^{\prime \prime} \mathrm{E}$ ), close to the French border, where it was introduced through the timber trade [92]. From southern France, it rapidly colonized the Tyrrhenian coast up to the western sector of the Tuscany region, attacking the maritime pine, its only host, and causing severe damage (Figure 3). The spread of this scale along the coast is linked both to wind, which scatters the preimaginal stages, and to the transport of infested trunks. The scale completes one generation per year; it lives in bark fissures, inserting its stylet into the tree's inner tissues from which it extracts sap. The remarkable fecundity of females allows the insect to quickly develop high-density populations, which can profoundly alter the composition of plant communities. An example is the scale-caused decline of the maritime pine stands along the Tyrrhenian coast, which has greatly damaged tourism.

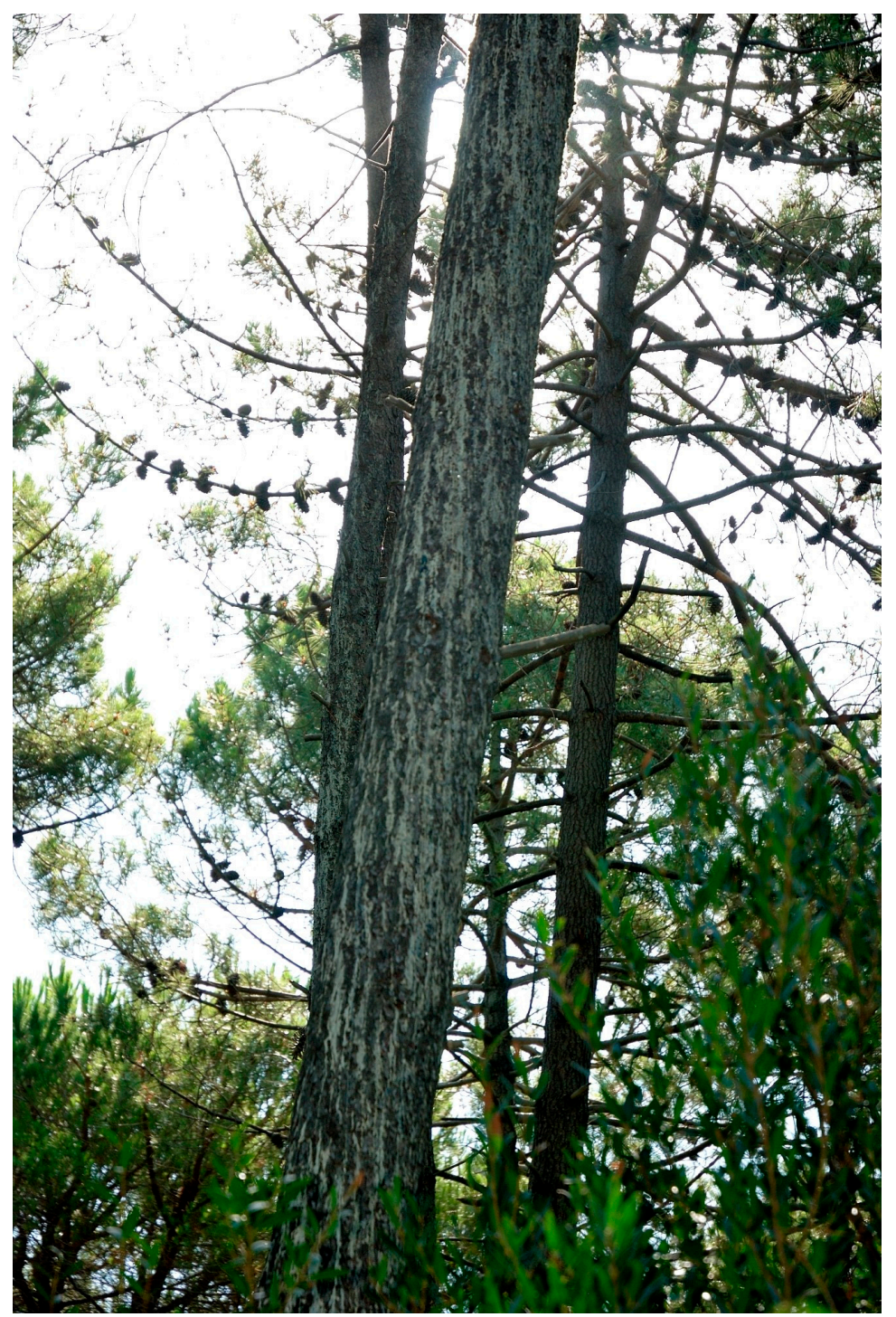

Figure 3. Copious exudation of resin on a maritime pine infested by Matsucoccus feytaudi. 
At present, 45 years after being first reported in Italy, the maritime pine bast scale retains its initial aggression levels, and concrete strategies to contain it have yet to be devised. In fact, all trials carried out have given uncertain, and generally unreliable, results. Public misinformation and opposition further complicates this matter by not approving the necessary phytosanitary felling. The ministerial decree ' $\mathrm{DM}^{\prime}$ ' of 22 November 1996, issued by the Italian Ministry of Agriculture (MiPAAF), and subsequently integrated and amended by the 'DM' of 10 November 2016, provides guidance and rules to be applied for the mandatory fight against this pest. In attacked areas, indigenous maritime pines could be progressively replaced by North African ecotypes, which seems to be tolerant to $M$. feytaudi [93]. This could be a possible solution to the problem; in fact, since eradicating this insect has been shown to be impossible, a valid protocol that will enable at least some form of coexistence should now be formulated.

Leptoglossus occidentalis Heidemann (Hemiptera: Coreidae), a North American insect, was accidentally introduced into Italy in 1999, probably through the transportation of wintering adults inside shipping containers [94]. L. occidentalis L. feeds on the green tissues and cones of conifer hosts; the damage is economically disastrous when it attacks the cones (Figure 4) and seeds of the stone pine [95], directly hurting the nut industry. Furthermore, stone pines typify the landscape in the coastal areas of many central and southern Italian regions; their waning could cause economic losses in the tourism sector.

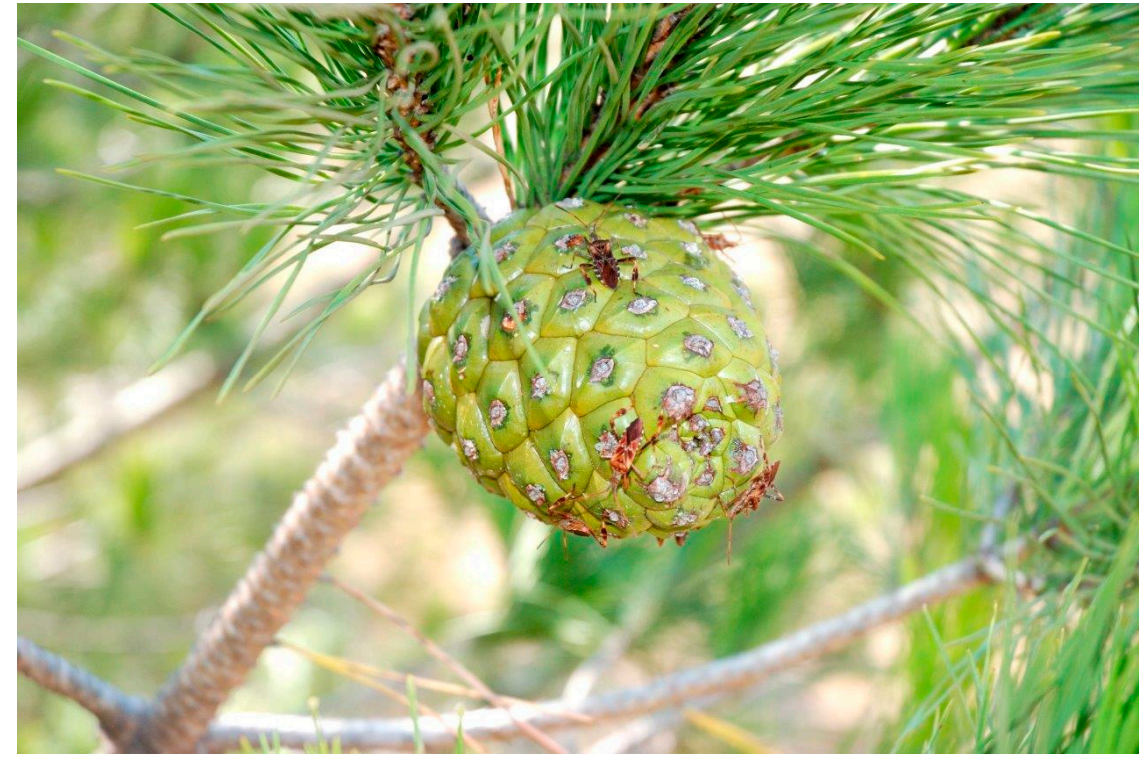

Figure 4. Several Leptoglossus occidentalis adults feeding at the expense of a three-year stone pine cone.

\section{Main Microbial Pathogens and Pests of Impending Introduction}

Among the numerous species listed by the EPPO (European and Mediterranean Plant Protection Organization), and which may soon be introduced into Italy, we mention here those capable of devastating consequences for their hosts.

\subsection{Fungi and Chromista}

Among the fungi, Ceratocystis fagacearum (Bretz) J. Hunt (anamorphic Endoconidiophora fagacearum Bretz.), the agent of "oak wilt", deserves the utmost attention. This parasite penetrates wounds, and causes extensive damage to forest and urban trees, infecting, in addition to oaks, even some varieties of the Castanea genus. This fungus is common in the United States, especially in the Great Lakes region, and there are fears that it may be introduced into Europe. In terms of symptoms, the pathogen mainly induces a yellowing of the leaves, which then turn brown and wither; this infectious process proceeds 
from the apex towards the bottom of the crown, causing crown wilting. Disease progression is very fast, and, within one or two months after infection, the tree may die. Another extremely important aspect is that various pests associated with oaks can carry the fungal propagules. In Europe, particularly susceptible oaks include: Turkey oak, holm oak (Q. ilex L.), English oak (Q. robur L.), pubescent oak, and cork oak (Q. suber L.).

The rust fungi (Pucciniales) are among the most harmful and destructive fungal plant pathogens worldwide [96]. It is thus no coincidence that they represent one of the largest groups of quarantine pathogens in the EPPO lists, counting important members of the genera Chrysomixa, Cronartium, Endocronartium, Gymnosporangium, Melampsora, Puccinia, and Thekopsora. The possible introduction of exotic members of this group is strongly feared in Italy, and, therefore, they must be closely monitored. Among these fungi, the species belonging to the genus Cronartium are particularly virulent and dangerous; some members of this genus infect oaks and pines, tree species which are widely used in both forest stands and urban plantations.

Particularly dreaded is Cronartium quercuum f.sp. fusiforme (Berk.) Miyabe ex Shirai, the agent behind "fusiform rust". Native to North America, this heteroecious (i.e., host-alternating) pathogen has as telial hosts oaks and chestnuts; in North America, the following species are particularly susceptible: Quercus cinerea Michx., Q. marilandica Muench., Q. nigra L., Q. rubra L., C. dentate Poir. , and C. mollissima Blume. It also infects Pinus in its aecial stage; in the United States, it has attacked Pinus banksiana Lamb., P. elliottii Engelm., P. palustris Mill., P. radiata D. Don, P. serotina Michx., P. taeda L., P. virginiana Mill., and other minor species. Potential hosts in Europe, and more specifically in Italy, are several species of the genus Quercus, C. sativa, P. halepensis, Pinus nigra laricio (Poir.) Maire, P. mugo Turra, P. nigra P.F. Arnold, P. pinea, and P. sylvestris L. Its dangerousness lies in the massive number of spores produced, its adaptability to the climatic conditions of our country, and the high survival ability of its urediniospores [97]. The death of twigs, branches, and the trunk is due to the thousands of sori erupting through the bark and often girdling the stem of infected pines.

Among the chromista, Phytophthora lateralis Tucker \& Milbrath is at risk of being introduced in Italy. It is a widespread parasite in the northwest of the United States and in Canada. It is already present in France, Holland, and the UK [98-100]. Young plants (including seedlings), as well as adult specimens of Chamaecyparis spp. and Taxus sp., are particularly susceptible; in Italy, these species are frequently planted in parks, boulevards, and hedges. The leaves of attacked plants turn yellow and wither, then they darken and necrotize. Afterwards, the weakened plants become susceptible to bark beetle attacks, and ultimately die. At the same time, root rot undermines tree stability, thus increasing the risk of tree fall. Seedlings and young plants are killed quickly; in adults, the infection causes the necrosis of cortical tissue at the base of the collar and on the roots. The infected roots, which look "water-soaked", darken and then die in a short time.

\subsection{Phytophagous Pests (Insects and Nematodes)}

Following taxonomic order, we first would like to bring attention to the moth Malacosoma disstria (Hübner) (Lepidoptera: Lasiocampidae), which causes severe defoliation on many broadleaves and some conifers. It is widely distributed across North America, where it attacks many ornamental broadleaves which are often used in parks, gardens, and boulevards.

Secondly, we would like to point out the buprestid beetle, Agrilus planipennis (Fairmaire) (Coleoptera: Buprestidae), for the devastating impact that could follow its as-yet-hypothetical introduction. This xylophagous beetle is native to Eastern Russia, Northern China, Japan, and Korea. The species has already been reported in the United States and, therefore, given the frequent trade between Italy and North America, as well as with various central Asian countries, forthcoming introduction of this pest into Italy is highly probable. Its host plants are some broadleaves, with a particular preference for species of the Fraxinus genus. A. planipennis develops in the subcortical layers of host plants, and its presence is revealed by numerous adults' emergence holes on the bark of trunks 
and main branches. Attacked plants manifest vegetative decline with diffused chlorosis, phylloptosis, and necrosis of the branches, before ultimately dying.

Another phytosanitary concern involving insects as vectors, is the dreaded nematode Bursaphelenchus xylophilus (Steiner et Buhrer), a parasite of conifers, especially pines. This species' native range is North America, whence it was introduced into East Asia; recently, it has been reported in the pine forests of Portugal, Spain [101], France, and in Scandinavian countries due to timber imported from North America. Several insects, mainly longhorn beetles of the Monochamus Dejean genus, which attack the lignified structures of conifers (including pines), favor this parasite's spread [102].

\section{Management and Control}

More than half (56\%) of rising phytosanitary problems are caused by the introduction of alien plant diseases and pests into new geographic areas, where they become invasive species; a further $25 \%$ of cases are linked to climatic conditions [103]. For these reasons, proper control strategies are required. Prevention and early diagnosis are essential to thwart invasive alien species that may threaten the green heritage of our cities. If these strategies prove to be ineffective, then complex measures, such as eradication of the newly introduced invasive species, must be enacted. Thus, the current concept of "plant biosecurity" must include the joint effort of politics, law, technology, and science, each sector with its own, defined, roles and responsibilities.

In urban settings, plants-many of which are introduced and therefore poorly adapted to local microclimates-often grow under harsh environmental conditions (e.g., soil compaction, water deficit, anoxia, heat stress, etc.). Surviving these precarious or adverse environmental conditions physiologically impairs and weakens plants, thus making them more prone to pathogen and insect attacks. Furthermore, urban agglomerates are centers for collecting invasive alien organisms before spreading them to their surrounding territories. Trade in plant material has grown exponentially in the past few decades, due to increasing ease in handling of the goods, city-dwellers' growing demand for green spaces, and, finally, the need to reduce pollution and mitigate climate change [104]. This has boosted the number of ornamental shrubs and trees being introduced into urban areas, which subsequently spread alien pathogens and pests into the wider rural environment [15]. Prevention and early diagnosis in urban areas are thus the first line of defense and the most effective means to safeguard territories from the invasion of pathogens and pests. This is also because, once an invasive species has established in a new territory, it is extremely difficult, as well as expensive, to eradicate it.

Monitoring is the best prevention method because monitoring protocols help prevent the accidental introduction of an exotic species into a given territory, or range expansion of a native species (thus converting it into an alien and invasive species) in areas that were previously pathogenor pest-free. Constant monitoring through reports and georeferenced monitoring would be of great aid [105]. However, the highest amount of effectiveness is achieved by permanent monitoring in defined areas, whose planning and maintenance are certainly complex and onerous, both in terms of financial resources and personnel, but which would ensure the immediate detection of unwanted entities [106]. Crucial steps in prevention are: identifying all potentially invasive parasitic species; pinpointing the most susceptible areas for future invasions and establishment (although the high variability among the various regions in their volume of commerce and thus in the rate of arrival of potential invaders, makes such predictions very difficult); and, above all, ascertaining their natural or human-assisted introduction pathways.

The International Plant Protection Convention (IPPC) and the EPPO are two institutions that enact and carry out inspections to prevent the introduction and spread of pests (insects and nematodes), infectious agents (fungi, bacteria, phytoplasmas, viruses, and virus-like organisms), and invasive plants, i.e., parasitic plants and those acting as potential vectors. Since 1970, the EPPO has maintained updated lists of these quarantine organisms, and the risk classes concerning the expansion of their original distribution range. The EPPO also works at developing and recommending international strategies (to be adopted at local or national level) against the introduction and spread of dangerous 
diseases and pests, as well as at promoting safe and effective control methods. Some of the strategies that can be used by local and national Plant Health Inspection Services to prevent the introduction and the spread of an alien species over a territory are: (i) risk assessment and evaluation of environmental impact; (ii) enactment of quarantine regulations and their application through monitoring inspections; (iii) trade restrictions; and (iv) treatment of imported materials (through fumigation, immersion in chemical or non-chemical compounds, sterilization, etc.).

In case preventive measures, early detection, or identification fail, eradication should be immediately performed. This operation aims to remove the entire alien population, by eliminating its nutritional, reproductive, and conservative niches. Obviously, any eradication program should be preceded by carefully weighing the costs against the probability of success. To be considered successful, an eradication program must: (i) be scientifically validated; (ii) be able to detect the niches of activity of the newly-introduced, dangerous organism; (iii) ensure that all individuals of the target population are susceptible to the chosen protocol(s); (iv) ensure that the legal and institutional framework allows for the application of the eradication program in a given country; (v) include a subsequent check to ensure that the objective has been reached; (vi) make sure that the techniques applied are environmentally, socially, and ethically acceptable; and (vii) include any measures necessary for restoring the structure and full functionality of ecosystems after the elimination of the invasive species.

In cases where eradication is not applicable, another strategy must be applied: containment. This form of control limits the spread of an introduced harmful organism by numerically reducing its population so that it does not impair the functionality of the ecosystem, thereby restricting it to a certain geographical area. The methods used are the same as those described for eradication. A major issue of containment programs is being able to quickly locate and identify new infections/infestations of species at risk of expansion, in the same containment areas or in new ones, so that control measures can be immediately implemented. Reducing the density and abundance of an invasive exotic species to below a preset acceptable threshold is the goal of control programs. Bringing a non-native species population under these thresholds can also favor native species, boosting their response. In theory, all control methods (chemical, physical, and biological) can be used, of course depending on the environment (forest or urban system), but not all of them are practical, effective, or economically and environmentally sustainable; for example, chemical control is absolutely prohibited in forest and urban ecosystems. In these contexts, control measures should be integrated to maximize their success while minimizing the environmental impact. In forest plantations, many strategies effectively control alien pathogens and insect pests: implementing suitable cultivation techniques; defining buffer zones; using resistant plant material; adopting biological control; and, finally, last but certainly not least, integrating pest and disease management tactics. In urban and peri-urban forests, the methods outlined in the preceding paragraph apply as long as they are environmentally friendly and take due account of the safeguard and well-being of citizens.

\section{Conclusions}

In conclusion, an interdisciplinary approach is fundamental to understanding, preventing, and reducing the harmful effects of invasive alien plant pathogens and pests in urban and peri-urban forests. Ecological, biological, recreational, social, economic, and legal aspects must all be taken into consideration when devising strategies to combat pest and pathogen attacks [107]. Research also plays a fundamental role; it must: deepen little-known aspects of the biology and epidemiology (including the development of forecasting models) of these damaging agents; develop accurate and advanced diagnostic techniques for the early detection of new invaders; track their introduction pathways; inform lawmakers about appropriate quarantine measures; and, lastly, provide phytosanitary inspection services with the most suitable control measures.

Another critical point is EU legislative shortcomings in protective measures against the introduction of organisms harmful to plants or plant products. It is opportune to fill these legislative gaps in the Community plant health regimes by implementing some preventive and/or corrective legal 
actions and by promoting more incisive and restrictive actions at the local, national, and Community level. The introduction of non-native species into the Community's territory has been encouraged by the lack of uniformity among the member states of phytosanitary control standards applied at the external EU customs barriers. Consequently, perfecting coordination between the different countries, unifying legislation in order to eliminate the disconnection between international and national laws, and establishing sanctions for countries not respectful of EU phytosanitary legislation are priorities [108]. In this regard, it is worth mentioning that, in Italy, a legislative decree is currently being issued on "the prevention and management of the introduction and spread of invasive alien species" to adapt national legislation to Community law (EU Regulation No. 1143/2014 of the European parliament and of the council of 22 October 2014). This decree, among other things, aims to solve an important critical issue concerning biological control, for example, if the natural enemies of the invasive pathogen/insect have to be allowed to enter. Specifically, it implies authorization to use exotic antagonists if the alien organism is so damaging as to impact the best interests of the nation, i.e., with social and economic consequences.

The choice of the control or containment measures directly impacts the value of ecosystem services and, ultimately, the quality of life of citizens [109]. Not by chance, "citizen science", with ecological data collection, environmental education, and nature observation, has become a priority of many environmental research programs funded by the EU (e.g., the Observatree project, https://www. observatree.org.uk). Additionally, in recent years, it has become strategic to engage citizens in territory monitoring for the early detection of newly introduced plant pathogens and pests [110]. The effective contribution of citizen science in early warning systems for invasive organisms has already been proven in southern Europe [111]. The contribution of these non-professional volunteers in data-collection and monitoring campaigns is made even more effective if it is accompanied by adequate public information and education to ensure high data quality [112]. Data quality checks, extensive coverage, and the use of statistically reliable methods would further improve these monitoring protocols.

Acknowledgments: The authors wish to thank the Foundation "Cassa di Risparmio di Firenze" for financial support. We thank anonymous reviewers for comments and discussion.

Author Contributions: S.M. and T.P. designed the study, identified its content and structure, interpreted data, and wrote the manuscript; M.B., F.C. and S.C. helped write the manuscript; R.T. and A.R. critically reviewed the manuscript.

Conflicts of Interest: The authors declare no conflicts of interest.

\section{References}

1. Boyd, I.L.; Freer-Smith, P.H.; Gilligan, C.A.; Godfray, H.C.J. The Consequence of tree pests and diseases for ecosystem services. Science 2013, 342, 1235773. [CrossRef] [PubMed]

2. Pimentel, D.; Lach, L.; Zuniga, R.; Morrison, D. Environmental and economic costs of nonindigenous species in the United States. Bioscience 2000, 50, 53-65. [CrossRef]

3. Zhang, P.; Shao, G.; Zhao, G.; Le Master, D.C.; Parker, G.R.; Dunning, J.B.; Li, Q. China's forest policy for the 21st century. Science 2000, 288, 2135-2136. [CrossRef] [PubMed]

4. Mooney, H.A.; Zavaleta, E.S.; Hobbs, R.J. Invasive alien species- are we up to the challenge? In Managing Weeds in a Changing Climate, Proceedings of the 15th Australian Weeds Conference, Adelaide, South Australia, 24-28 September 2006; Preston, C., Watts, J.H., Crossman, N.D., Eds.; Weed Management Society of South Australia: Torrens Park, Adelaide, Australia, 2006; pp. 1-5.

5. Lockwood, J.L.; Hoopes, M.F.; Marchetti, M.P. Invasion Ecology; Blackwell Publishing: Oxford, UK, 2007.

6. Preston, C.D.; Pearman, D.A.; Hall, A.R. Archaeophytes in Britain. Bot. J. Linn. Soc. 2004, 145, $257-294$. [CrossRef]

7. Perrings, C.S.; Dalmazzone, S.; Williamson, M. The economics of biological invasions. In Invasive Alien Species: A New Synthesis; Island Press: Washington, DC, USA, 2005; pp. 16-35.

8. Meyerson, L.A.; Mooney, H.A. Invasive alien species in an era of globalization. Front. Ecol. Environ. 2007, 5, 199-208. [CrossRef] 
9. Schönrogge, K.; Moryia, S.; Melika, G.; Randle, Z.; Begg, T.; Aebi, A.; Stone, G. Early parasitoid recruitment in invading cynipid galls. In Galling Arthropods and their Associates: Ecology and Evolution; Ozaki, K., Yukawa, J., Ohgushi, T., Price, P.W., Eds.; Springer: Tokyo, Japan, 2006; pp. 91-102.

10. Hitch, A.T.; Leberg, P.L. Breeding distributions of North American bird species moving north as a result of climate change. Conserv. Biol. 2007, 21, 534-539. [CrossRef] [PubMed]

11. Beaumont, L.J.; Gallagher, R.V.; Thuiller, W.; Downey, P.O.; Leishman, M.R.; Hughes, L. Different climatic envelopes among invasive populations may lead to underestimations of current and future biological invasions. Divers. Distrib. 2009, 15, 409-420. [CrossRef]

12. Engler, R.; Guisan, A. MigClim: Predicting plant distribution and dispersal in a changing climate. Divers. Distrib. 2009, 15, 590-601. [CrossRef]

13. Heino, J.; Virkkala, R.; Toivonen, H. Climate change and fresh water biodiversity: Detected patterns, future trends adaptations in northern regions. Biol. Rev. Camb. Philo. Soc. 2009, 84, 39-54. [CrossRef] [PubMed]

14. Jeschke, J.M.; Strayer, D.L. Invasion success of vertebrates in Europe and North America. Proc. Natl. Acad. Sci. USA 2005, 102, 7198-7202. [CrossRef] [PubMed]

15. Tubby, K.V.; Webber, J.F. Pests and diseases threatening urban trees under a changing climate. Forestry 2010, 83, 451-459. [CrossRef]

16. Smiley, E.T.; Matheny, N.; Lilly, S. Best Management Practices Tree Risk Assessment; ISA: Champaign, IL, USA, 2011.

17. Brasier, C.M. Intercontinental Spread and Continuing Evolution of the Dutch Elm Disease Pathogens; Kluwer Academic Publishers: Boston, MA, USA, 2000; pp. 61-72.

18. Brasier, C.M.; Kirk, S.A. Designation of the EAN and NAN races of Ophiostoma novo-ulmi as subspecies. Mycol. Res. 2001, 105, 547-554. [CrossRef]

19. Brasier, C.M.; Buck, K.W.; Paoletti, M.; Crawford, L.; Kirk, S.A. Molecular analysis of evolutionary changes in populations of Ophiostoma novo-ulmi. For. Syst. 2004, 13, 93-103.

20. Scala, A.; Pattuelli, M.; Coppola, L.; Guastini, M.; Tegli, S.; Del Sorbo, G.; Mittempergher, L.; Scala, F. Dutch elm disease progression and quantitative determination of cerato-ulmin in leaves, stems and branches of elms inoculated with Ophiostoma novo-ulmi and O. ulmi. Physiol. Mol. Plant Pathol. 1997, 50, 349-360. [CrossRef]

21. Panconesi, A. Il rinvenimento della Ceratocystis fimbriata (Ell. et Halst.) Davidson f. platani Walter su Platano. Riv. Patol. Veg. 1973, 9, 167-188.

22. Scala, A.; Pazzagli, L.; Comparini, C.; Santini, A.; Tegli, S.; Cappugi, G. Cerato-platanin, an early-produce protein by Ceratocystis fimbriata f. sp. platani, elicits phytoalexin synthesis in host and non-host plants. J. Plant Pathol. 2004, 86, 23-29.

23. Capretti, P.; Mugnai, L. Disseccamenti di cerro da Hypoxylon mediterraneum (De Not.) Mill. Inf. Fitopatol. 1987, 37, 39-41.

24. Ragazzi, A.; Ginetti, B.; Moricca, S. First report of Biscogniauxia mediterranea on English Ash in Italy. Plant Dis. 2012, 96, 1694. [CrossRef]

25. Ragazzi, A.; Moricca, S. Il patosistema "endofita/specie arborea forestale" ed i cambiamenti climatici: Analisi di un caso di studio. Micol. Ital. 2012, 2-3, 11-27.

26. Grünwald, N.J.; Garbelotto, M.; Goss, E.M.; Heungens, K.; Prospero, S. Emergence of the sudden oak death pathogen Phytophthora ramorum. Trends Microbiol. 2012, 20, 131-138. [CrossRef] [PubMed]

27. Webber, J.F.; Mullet, M.; Brasier, C.M. Dieback and mortality of plantation Japanese larch (Larix kaempferi) associated with infection by Phytophthora ramorum. New Dis. Rep. 2010, 22, 19. [CrossRef]

28. Gullino, C.; Garofalo, M.C.; Moretti, F.; Gianetti, G.; Mainenti, E. Rinvenimento su rododendro di Phytophthora ramorum. Inf. Agrar. 2003, 19, 87-89.

29. Ginetti, B.; Carmignani, S.; Ragazzi, A.; Werres, S.; Moricca, S. Foliar blight and shoot dieback caused by Phyophthora ramorum on Viburnum tinus in the Pistoia area, Tuscany, central Italy. Plant Dis. 2014, $98,423$. [CrossRef]

30. Brasier, C.; Webber, J. Plant pathology: Sudden larch death. Nature 2010, 466, 824-825. [CrossRef] [PubMed]

31. Garbelotto, M.; Schmidt, D.; Swain, S.; Hayden, K.; Lione, G. The ecology of infection between a transmissive and a dead-end host provides clues for the treatment of a plant disease. Ecosphere 2017, 8, e01815. [CrossRef]

32. Moricca, S.; Ragazzi, A. Lusus naturae: Cambiamenti climatici ed invasioni di parassiti vegetali modificano il territorio agro-forestale. Ital. J. Agron. 2009, 3, 13-17. [CrossRef] 
33. Milgroom, M.G.; Wang, K.; Zhou, Y.; Lipari, S.E.; Kaneko, S. Intercontinental population structure of the chestnut blight fungus, Cryphonectria parasitica. Mycologia 1996, 88, 179-190. [CrossRef]

34. Milgroom, M.G.; Cortesi, P. Biological control of chestnut blight with hypovirulence: A critical analysis. Annu. Rev. Phytopathol. 2004, 42, 331-638. [CrossRef] [PubMed]

35. Gross, A.; Holdenrieder, O.; Pautasso, M.; Queloz, V.; Sieber, T.N. Hymenoscyphus pseudoalbidus, the causal agent of European ash dieback. Mol. Plant Pathol. 2014, 15, 5-21. [CrossRef] [PubMed]

36. Kowalski, T. O zamieraniu jesionów. Trybuna Leśnika 2001, 4, 6-7.

37. Kowalski, T. Chalara fraxinea sp. nov. associated with dieback of ash (Fraxinus excelsior) in Poland. For. Pathol. 2006, 36, 264-270. [CrossRef]

38. Baral, H.O.; Queloz, V.; Hosoya, T. Hymenoscyphus fraxineus, the correct scientific name for the fungus causing ash dieback in Europe. IMA Fungus 2014, 5, 79-80. [CrossRef] [PubMed]

39. Zhao, Y.J.; Hosoya, T.; Baral, H.O.; Hosaka, K.; Kakishima, M. Hymenoscyphus pseudoalbidus, the correct name for Lambertella albida reported from Japan. Mycotaxon 2012, 122, 25-41. [CrossRef]

40. Ogris, N.; Hauptman, T.; Jurc, D.; Floreancig, V.; Marsich, F.; Montecchio, L. First Report of Chalara fraxinea on Common Ash in Italy. Plant Dis. 2010, 94, 133. [CrossRef]

41. Giongo, S.; Oliveira Longa, C.M.; Dal Maso, E.; Montecchio, L.; Maresi, G. Evaluating the impact of Hymenoscyphus fraxineus in Trentino (Alps, Northern Italy): First investigations. iForest 2017, 10, 871-878. [CrossRef]

42. Luchi, N.; Ghelardini, L.; Santini, A.; Migliorini, D.; Capretti, P. First Record of Ash Dieback Caused by Hymenoscyphus fraxineus on Fraxinus excelsior in the Apennines (Tuscany, Italy). Plant Dis. 2016, 100, 535. [CrossRef]

43. Ginetti, B.; Moricca, S.; Squires, J.N.; Cooke, D.E.L.; Ragazzi, A.; Jung, T. Phytophthora acerina sp.nov., a new species causing bleeding cankers and dieback of Acer pseudoplatanus trees in planted forests in Northern Italy. Plant Pathol. 2014, 63, 858-876. [CrossRef]

44. Panconesi, A. Il Cipresso, Dalla Leggenda al Futuro. Istituto per la Protezione Delle Piante; CNR: Sesto Fiorentino, Italy, 2007.

45. Graniti, A. Cypress canker: A Pandemic in Progress. Annu. Rev. Phytopathol. 1998, 36, 91-114. [CrossRef] [PubMed]

46. Gonthier, P.; Lione, L.; Giordano, L.; Garbelotto, M. The American forest pathogen Heterobasidion irregulare colonizes unexpected habitats after its introduction in Italy. Ecol. Appl. 2012, 22, 2135-2143. [CrossRef] [PubMed]

47. Panconesi, A.; Moricca, S.; Ragazzi, A.; Dellavalle, I.; Tiberi, R. Parassiti Delle Piante Arboree Forestali ed Ornamentali. Specie Introdotte e di Temuta Introduzione; Pàtron Editore: Bologna, Italy, 2014.

48. Carlucci, A.; Colatruglio, L.; Frisullo, S. First report of pitch canker caused by Fusarium circinatum on Pinus halepensis and P. pinea in Apulia (Southern Italy). Plant Dis. 2007, 91, 1683. [CrossRef]

49. Schweigkofler, W.; O'Donnell, K.; Garbelotto, M. Detection and quantification of airborne conidia of Fusarium circinatum, the causal agent of pine pitch canker, from two California sites by using a real-time PCR approach combined with a simple spore trapping method. Appl. Environ. Microb. 2004, 70, 3512-3520. [CrossRef] [PubMed]

50. Gordon, T.R.; Storer, A.J.; Wood, D.L. The pitch canker epidemic in California. Plant Dis. 2001, 85, 1128-1139. [CrossRef]

51. Saponari, M.; Boscia, D.; Nigro, F.; Martelli, G.P. Identification of DNA sequences related to Xylella fastidiosa in oleander, almond and olive trees exhibiting leaf scorch symptoms in Apulia (southern Italy). J. Plant Pathol. 2013, 95, 659-668.

52. Redak, R.A.; Purcell, A.H.; Lopes, J.R.; Blua, M.J.; Mizell, R.F. The biology of xylem fluid-feeding insect vectors of Xylella fastidiosa and their relation to disease epidemiology. Annu. Rev. Entomol. 2004, 49, $243-270$. [CrossRef] [PubMed]

53. Crosse, J.E.; Bennett, M.; Garrett, C.M.E. Fire-blight of pear in England. Nature 1958, 182, 1530. [CrossRef]

54. Cariddi, C.; Piglionica, V. First record of fire blight in Italy. Phytoparasitica 1992, 19, 265-266.

55. Bonn, W.G.; van der Zwet, T. Distribution and economic importance of fire blight. In Fire Blight: The Disease and Its Causative Agent, Erwinia amylovora; Vanneste, J.L., Ed.; CABI: Wallingford, UK, 2000; pp. 37-53.

56. Mazzucchi, U. The fireblight monitoring network in northern Italy: Origin and development. Bull. OEPP 1994, 24, 783-791. [CrossRef] 
57. Pucci, N.; L'Aurora, A.; Loreti, S. Fire blight: First report in Latium, Italy. J. Plant Pathol. 2013, 95, 663.

58. EPPO RS 2011/198. PQR - The EPPO Database on Quarantine Pests: New Update. Available online: http:/ / archives.eppo.int/EPPOReporting/Reporting_Archives.htm (accessed on 24 November 2017).

59. EPPO RS 2013/223. Aproceros leucopoda Found for the First Time in the Autonomous Province of Trento (IT). Available online: http://archives.eppo.int/EPPOReporting/Reporting_Archives.htm (accessed on 24 November 2017).

60. Zandigiacomo, P.; Cargnus, E.; Villani, A. First record of the invasive sawfly Aproceros leucopoda infesting elms in Italy. Bull. Insectol. 2011, 64, 145-149.

61. Servadei, A. Un tingide neartico comparso in Italia (Corythucha ciliata Say). Boll. Soc. Entomol. Ital. 1966, 96, 94-96.

62. Butin, H.; Führer, E. Die Rosskastanien-Miniermotte (Cameraria ohridella Deschka \& Dimic) ein neuer Schädling an Aesculus hippocastanum. Nachr. Deutschen Planzenschutzd. 1992, 46, 89-91.

63. Panzavolta, T.; Sabbatini Peverieri, G.; Marziali, L.; Tiberi, R. Prime notizie bio-ecologiche su Cameraria ohridella. E. M. Linea Ecol. 2002, 3, 54-60.

64. Brussino, G.; Bosio, G.; Baudino, M.; Giordano, R.; Ramello, F.; Melika, G. Pericoloso insetto esotico per il castagno europeo. Inf. Agrar. 2002, 37, 59-61.

65. Melika, G.; Brussino, G.; Bosio, G.; Csoka, G. Chestnut gall wasp (Dryocosmus kuriphilus Yasumatsu 1951-Hymenoptera: Cynipidae), a new pest of chestnuts in Europe. Novenyvedelem 2002, 39, 59-63.

66. Espinosa, B.; Muccio, P.; Di Russo, G. Paysandisia archon, una minaccia per le nostre palme. Inf. Agrar. 2003, $59,61$.

67. Sacchetti, P.; Camera, A.; Granchietti, A.; Rosi, M.C.; Marzialetti, P. Prima segnalazione in Italia del curculionide delle palme, Rhynchophorus ferrugineus. Not. Centro Vivaismo Pistoia 2005, 144, 6-9.

68. Dembilio, Ó.; Jacas, J.A. Bio-ecology and integrated management of the red palm weevil, Rhynchophorus ferrugineus (Coleoptera: Curculionidae), in the region of Valencia (Spain). Hell. Plant Prot. J. 2012, 5, 1-12.

69. Ippolito, R.; Parenzan, P. Osservazioni su catture di Lepidotteri in Agro di Polignano (Bari). Entomologica 1981, 16, 143-182.

70. Zangheri, S.; Donadini, P. Comparsa nel Veneto di un omottero neartico: Metcalfa pruinosa Say (Homoptera, Flatidae). Redia 1980, 63, 301-305.

71. Colombo, M.; Limonta, L. Anoplophora malasiaca Thomson (Coleoptera Cerambycidae Lamiinae Lamiini) in Europe. Boll. Zool. Agrar. Bachic. 2001, 33, 65-68.

72. Maspero, M.; Jucker, C.; Colombo, M. First record of Anoplophora glabripennis (Motschulsky) (Coleoptera Cerambycidae Lamiinae Lamiini) in Italy. Boll. Zool. Agrar. Bachic. 2007, 39, 161-164.

73. EPPO RS 2008/194. Anoplophora chinensis Found for the First Time in Roma (IT). Available online: http: / / archives.eppo.int/EPPOReporting/Reporting_Archives.htm (accessed on 24 November 2017).

74. EPPO RS 2014/142. New Outbreak of Anoplophora chinensis in Italy. Available online: http:/ / archives.eppo. int/EPPOReporting/Reporting_Archives.htm (accessed on 24 November 2017).

75. EPPO RS 2009/157. Anoplophora glabripennis Detected in the Veneto Region, Italy. Available online: http: / / archives.eppo.int/EPPOReporting/Reporting_Archives.htm (accessed on 24 November 2017).

76. EPPO RS 2014/010. Update on the Situation of Anoplophora glabripennis in Veneto Region (IT). Available online: http:/ / archives.eppo.int/EPPOReporting/Reporting_Archives.htm (accessed on 24 November 2017).

77. EPPO RS 2014/064. Updated Situation of Anoplophora glabripennis in Marche Region, Italy. Available online: http:/ / archives.eppo.int/EPPOReporting/Reporting_Archives.htm (accessed on 24 November 2017).

78. Pennacchio, F.; Roversi, P.F.; Francardi, V.; Gatti, E. Xylosandrus crassiusculus (Motschulsky) a bark beetle new to Europe (Coleoptera Scolytidae). Redia 2003, 86, 77-80.

79. EPPO RS 2009/054. A New Ambrosia Beetle, Xylosandrus crassiusculus, Detected in Italy: Addition to the EPPO Alert List. Available online: http://archives.eppo.int/EPPOReporting/Reporting_Archives.htm (accessed on 24 November 2017).

80. EPPO RS 2010/031. Update on the Situation of Xylosandrus crassiusculus in Italy. Available online: http: / / archives.eppo.int/EPPOReporting/Reporting_Archives.htm (accessed on 24 November 2017).

81. EPPO RS 2013/013. Xylosandrus crassiusculus: New Detections in Liguria (Northern Italy). Available online: http:/ / archives.eppo.int/EPPOReporting/Reporting_Archives.htm (accessed on 24 November 2017).

82. Stergulc, F.; Frigimelica, G.; Zandigiacomo, P.; Battisti, A. Gravi deperimenti del noce comune in giovani impianti da legno in Friuli-Venezia Giulia. Sherwood 1999, 44, 27-30. 
83. CABI. Xylosandrus germanus (Black Timber Bark Beetle). Datasheet 2015. Available online: http://www.cabi. org/isc/datasheet/57237 (accessed on 24 November 2017).

84. Galko, J. First record of the ambrosia beetle, Xylosandrus germanus (Blandford, 1894) (Coleoptera: Curculionidae, Scolytinae) in Slovakia. For. J. 2013, 58, 274-279.

85. Longo, S. Un Nuovo Cerambicide Xilofago Introdotto in Italia. Georgofili Info. Notiziario di Informazione su Agricoltura, Ambiente, Alimentazione a Cura dell'Accademia dei Georgofili. 2013. Available online: www.georgofili.info (accessed on 24 November 2017).

86. EPPO RS 2012/204. First Report of Aromia bungii in Italy. Available online: http://archives.eppo.int/ EPPOReporting/Reporting_Archives.htm (accessed on 24 November 2017).

87. EPPO RS 2013/187. Aromia bungii Found for the First Time in Lombardia Region, Italy. Available online: http:/ / archives.eppo.int/EPPOReporting/Reporting_Archives.htm (accessed on 24 November 2017).

88. EPPO. EPPO datasheet on pests recommended for regulation. EPPO Bull. 2015, 45, 4-8.

89. Pavesi, M. Popillia japonica specie aliena invasiva segnalata in Lombardia. L'Inf. Agrar. 2014, 32, 53-55.

90. EPPO RS 2014/179. First Report of Popillia japonica in Italy. Available online: http://archives.eppo.int/ EPPOReporting/Reporting_Archives.htm (accessed on 24 November 2017).

91. Allsopp, P.G. Japanese beetle, Popillia japonica Newman (Coleoptera: Scarabaeidae): Rate of movement and potential distribution of an immigrant species. Coleopt. Bull. 1996, 50, 81-95.

92. Arzone, A.; Vidano, C. Matsucoccus feytaudi Duc. (Homoptera, Margarodidae), fitomizo letale a Pinus pinaster Ait. in Italia. Inf. Fitopatol. 1981, 31, 3-10.

93. Fusaro, E.; Righi, F.; Di Matteo, G. Selezione di provenienze di Pinus pinaster resistenti a Matsucoccus feytaudi. In Proceedings of the Atti del III Congresso Nazionale di Selvicoltura per la conservazione e il miglioramento dei boschi, Taormina, Italy, 16-19 October 2008.

94. Tescari, G. Leptoglossus occidentalis, coreide neartico rinvenuto in Italia (Heteroptera, Coreidae). Lav. Soc. Ven. Sci. Nat. 2001, 26, 3-5.

95. Bracalini, M.; Benedettelli, S.; Croci, F.; Terreni, P.; Tiberi, R.; Panzavolta, T. Cone and seed pests of Pinus pinea: Assessment and characterization of damage. J. Econ. Entomol. 2013, 106, 229-234. [CrossRef] [PubMed]

96. Kolmer, J.A.; Ordonez, M.E.; Groth, J.V. The rust fungi. In Encyclopedia of Life Sciences (ELS); John Wiley \& Sons, Ltd.: Chichester, UK, 2009.

97. Ragazzi, A. La ruggine fusiforme dei pini americani: Cronartium quercuum (Berk.) Myabe ex Shirai f.sp. fusiforme. Monti Boschi 1989, 40, 39-44.

98. Sansford, C.E. Development of U.K. EU/EPPO Pest Risk Analyses for Phytophthora kernoviae, P. ramorum and P. lateralis. In Phytophthora in Forests and Natural Ecosystems, Proceedings of the 4th Meeting of the International Union of Forest Research Organizations (IUFRO) Working Party S07.02.09, Monterey, CA, USA, 26-31 August 2007; Goheen, E.M., Frankel, S.J., Eds.; U.S. Department of Agriculture, Forest Service, Pacific Southwest Research Station: Albany, CA, USA, 2009; pp. 139-153.

99. Robin, C.; Piou, D.; Feau, N.; Douzon, G.; Schenck, N.; Hansen, E.M. Root and aerial infections of Chamaecyparis lawsoniana by Phytophthora lateralis: A new threat for European countries. Forest Pathol. 2011, 41, 417-424. [CrossRef]

100. Green, S.; Brasier, C.M.; Schlenzig, A.; McCracken, A.; MacAskill, G.A.; Wilson, M.; Webber, J.F. The destructive invasive pathogen Phytophthora lateralis found on Chamaecyparis lawsoniana across the UK. Forest Pathol. 2013, 43, 19-28.

101. Abelleira, A.; Picoaga, A.; Mansilla, J.P.; Aguin, O. Detection of Bursaphelenchus xylophilus, causal agent of pine wilt disease on Pinus pinaster in Northwestern Spain. Plant Dis. 2011, 95, 776. [CrossRef]

102. Sousa, E.; Bravo, M.A.; Pires, J.; Naves, P.; Penas, A.C.; Bonifacio, L.; Mota, M. Bursaphelenchus xylophilus (Nematoda; Aphelenchoididae) associated with Monochamus galloprovincialis (Coleoptera, Cerambycidae) in Portugal. Nematology 2001, 3, 89-91. [CrossRef]

103. Anderson, P.K.; Cunningham, A.A.; Patel, N.G.; Morales, F.J.; Epstein, P.R.; Daszak, P. Emerging infectious diseases of plants: Pathogen pollution, climate change and agrotechnology drivers. Trends Ecol. Evol. 2004, 19, 535-544. [CrossRef] [PubMed]

104. Mariani, L.; Parisi, S.G.; Cola, G.; Lafortezza, R.; Colangelo, G.; Sanesi, G. Climatological analysis of the mitigating effect of vegetation on the urban heat island of Milan, Italy. Sci. Total Environ. 2016, 569-570, 762-773. [CrossRef] [PubMed] 
105. Yuan, L.; Bao, Z.; Zhang, H.; Zhang, Y.; Liang, X. Habitat monitoring to evaluate crop disease and pest distributions based on multi-source satellite remote sensing imagery. Optik 2017, 145, 66-73. [CrossRef]

106. Smith, D.; Smith, I.; Collett, N.; Elms, S. Forest health surveillance in Victoria. Austral. For. 2008, 71, $188-195$. [CrossRef]

107. Carrus, G.; Scopelliti, M.; Lafortezza, R.; Colangelo, G.; Ferrini, F.; Salbitano, F.; Sanesi, G. Go greener, feel better? The positive effects of biodiversity on the wellbeing of individuals visiting urban and peri-urban green areas. Landscape Urban Plan. 2015, 134, 221-228. [CrossRef]

108. Schrader, G.; Unger, J.G. Plant quarantine as a measure against invasive alien species: The framework of the international plant protection convention and the plant health regulations in the European Union. Biol. Invasions 2003, 5, 357-364. [CrossRef]

109. Bottalico, F.; Travaglini, D.; Chirici, G.; Garfi, V.; Giannetti, F.; De Marco, A.; Fares, S.; Marchetti, M.; Nocentini, S.; Paoletti, E.; et al. A spatially-explicit method to assess the dry deposition of air pollution by urban forests in the city of Florence, Italy. Urban For. Urban Gree. 2017, 27, 221-234. [CrossRef]

110. Dickinson, J.L.; Shirk, J.; Bonter, D.; Bonney, R.; Crain, R.L.; Martin, J.; Phillips, T.; Purcell, K. The current state of citizen science as a tool for ecological research and public engagement. Front. Ecol. Environ. 2012, 10, 291-297. [CrossRef]

111. Maistrello, L.; Dioli, P.; Bariselli, M.; Mazzoli, G.L.; Giacalone-Forini, I. Citizen science and early detection of invasive species: Phenology of first occurrences of Halyomorpha halys in Southern Europe. Biol. Invasions 2016, 18, 3109-3116. [CrossRef]

112. Crall, A.W.; Newman, G.J.; Jarnevich, C.S.; Stohlgren, T.J.; Waller, D.M.; Graham, J. Improving and integrating data on invasive species collected by citizen scientists. Biol. Invasions 2010, 12, 3419-3428. [CrossRef]

(C) 2018 by the authors. Licensee MDPI, Basel, Switzerland. This article is an open access article distributed under the terms and conditions of the Creative Commons Attribution (CC BY) license (http:/ / creativecommons.org/licenses/by/4.0/). 